University of Nebraska - Lincoln

DigitalCommons@University of Nebraska - Lincoln

Agronomy \& Horticulture -- Faculty Publications

Agronomy and Horticulture Department

2013

\title{
Sorghum Transformation: Overview and Utility
}

Tejinder Kumar

University of Nebraska-Lincoln, tejinderkumar@rediffmail.com

Arlene Howe

University of Nebraska-Lincoln

Shirley Sato

University of Nebraska-Lincoln, ssato1@unl.edu

Ismail M. Dweikat

University of Nebraska-Lincoln, idweikat2@unl.edu

Tom E. Clemente

University of Nebraska-Lincoln, tclemente1@unl.edu

Follow this and additional works at: https://digitalcommons.unl.edu/agronomyfacpub

Part of the Agricultural Science Commons, Agriculture Commons, Agronomy and Crop Sciences Commons, Horticulture Commons, Plant Breeding and Genetics Commons, Plant Pathology Commons, and the Weed Science Commons

Kumar, Tejinder; Howe, Arlene; Sato, Shirley; Dweikat, Ismail M.; and Clemente, Tom E., "Sorghum Transformation: Overview and Utility" (2013). Agronomy \& Horticulture -- Faculty Publications. 723. https://digitalcommons.unl.edu/agronomyfacpub/723

This Article is brought to you for free and open access by the Agronomy and Horticulture Department at DigitalCommons@University of Nebraska - Lincoln. It has been accepted for inclusion in Agronomy \& Horticulture -Faculty Publications by an authorized administrator of DigitalCommons@University of Nebraska - Lincoln. 
Published (as Chapter 10) in Andrew H. Paterson, ed., Genomics of the Saccharinae, Plant Genetics and Genomics: Crops and Models 11 (2013), pp. 205-221; doi: 10.1007/978-1-4419-5947-8_10

Copyright @ 2013 Springer Science+Business Media New York. Used by permission.

\title{
Sorghum Transformation: Overview and Utility
}

\author{
Tejinder Kumar, ${ }^{1}$ Arlene Howe, ${ }^{2,3}$ Shirley Sato, ${ }^{2}$ \\ Ismail Dweikat, ${ }^{1}$ and Tom Clemente ${ }^{1,2,4}$
}

1. Department of Agronomy \& Horticulture, University of Nebraska-Lincoln, 1400 R Street, Lincoln, NE 68583, USA

2. Center for Biotechnology, University of Nebraska-Lincoln,

Lincoln, NE 68588, USA

3. Monsanto Company, Chesterfield, MO 63017, USA

4. Center for Plant Science Innovation, University of Nebraska-Lincoln, Lincoln, NE 68588, USA

Corresponding author - Tejinder Kumar, email tejinderkumar@rediffmail.com

\begin{abstract}
Over the past decade genomics resources available for sorghum have rapidly expanded (Paterson Int J Plant Genomics 2008:6, 2008), these resources, coupled with the recent completion of the genome sequence which is relatively small in size $(730 \mathrm{Mb})$ (Paterson et al. Nature 457:551-556, 2009) makes sorghum a rather attractive species to study. Moreover, the USDA germplasm system maintains 42,614 accessions, of which more than 800 exotic landraces have been converted to day length-insensitive lines to facilitate their use in breeding programs. In addition, a set of EMS mutation stocks developed by the USDA
\end{abstract}


Plant Stress and Germplasm Development Unit in Lubbock, TX (Xin et al. Bioenerg Res 2:10-16, 2009) will be a valuable resource for functional genomics studies in sorghum. However, in order to be a robust system for study a suite of functional genomics tools are necessary to complement these other resources to aid in down-stream hypothesis testing. A key functional genomics tool is the ability to modulate gene expression through the introduction of transgenic genetic elements. This is exemplified by recent work (Cook et al. Plant Cell 22:867-887, 2010) in which RNAi experiments were employed to specifically reduced expression of two alkylresorcinol synthases to demonstrate their role in the synthesis of the allelopathic molecule sorgoleone. In addition to its value as a functional genomics tool, plant transformation offers a route to broaden access to novel input and output traits for sorghum breeding programs.

Keywords: Agrobacterium tumefaciens, Transformation, npt II, Biotechnology, Sorghum Genetic engineering

\section{Sorghum Transformation}

In general plant transformation can be partitioned into two components: competence of a cell for culture regeneration into a whole plant and receptiveness of that same cell for foreign DNA integration. In sorghum, like most monocotyledonous plants, in vitro culture regimes are primarily somatic embryogenesis based systems (Elkonin and Pakhomova 2000; Jogeswar et al. 2007; Kaeppler and Pedersen 1996; Pola et al. 2008; Pola and Mani 2006; Sato et al. 2004a). As per the second component of plant transformation, integration of genetic elements, sorghum has been successfully transformed using both direct DNA delivery methods (Battraw and Hall 1991) and Agrobacterium-mediated transformation protocols (Cai et al. 2002; Gao et al. 2005a, b; Gurel et al. 2009; Howe et al. 2006; Nguyen et al. 2007; Zhao et al. 2000). While both DNA delivery systems are proven technologies for recovery of stable sorghum transformants, more laboratories are moving towards implementing the latter due to the tendency of Agrobacteriummediated transformants to carry lower copy number insertions and/or have a higher frequency of coexpression of the nonselected transgenic cassette (Dai et al. 2001; Gao et al. 2008; Zhao et al. 1998).

While multiple explants have been evaluated as the starting material for sorghum transformation, clearly the primary explant reported on is immature embryos. One of the factors that have hampered transformation efficiencies of sorghum with the immature embryo explant is the rapid production of phenolic compounds. Phenolics are produced during the in vitro culturing of sorghum immature embryos, but the production of these secondary metabolites is enhanced upon inoculation with $A$. tumefaciens. To alleviate the negative effects of phenolics on sorghum transformation media supplements such as polyvinylpolypyrrolidone (PVPP) (Cai et al. 1987), and elevation of potassium phosphate levels (Elkonin and Pakhomova 2000; Sato et al. 2004a), or the exposure of explants to reduced temperature (Nguyen et al. 2007) have been shown to be able to reduce, but not totally eliminate the negative impact of these compounds. Triggering of the plant's defense response upon challenge with $A$. tumefaciens may lead not 
only to the production of secondary metabolites, but also to cell death, which can further hamper the efficiency of recovery of transgenic plants. For example in banana the triggering of apoptosis by $A$. tumefaciens can be effectively countered by the expression of antiapoptotic genes (Khanna et al. 2007). While such a strategy has not been evaluated in sorghum, a heat shock pretreatment, which was previously reported to counter apoptosis in banana embryogenic callus, leading to improved transformation efficiency (Khanna et al. 2004), has recently been shown to be a translatable technique using sorghum immature embryos (Gurel et al. 2009).

Key to any transformation system is the ability to rapidly, and efficiently distinguish transgenic differentiating cells from nontransgenic cell lineages. Two means typically used to differentiate transgenic from nontransgenic cell lineages are the use of visual or selectable marker genes. In sorghum the visual marker genes green fluorescent protein (gfp) and $\beta$-glucuronidase (GUS) are each effective in monitoring for transgenic cells (Jeoung et al. 2002). Using the former visual marker Gao et al. (2005a) reported a 3.0\% transformation efficiency as means to monitor for transgenic differentiating cell lineages from immature embryos of sorghum.

Selectable marker genes used to provide a competitive edge in culture for plant transformation systems typically rely upon providing resistance to antibiotics, such as hygromycin (Gritz and Davies 1983), and the aminoglycoside kanamycin, or various derivatives thereof (Fraley et al. 1983) or tolerance towards herbicidal agents glyphosate (Barry et al. 1992) and glufosinate (Thompson et al. 1987). In addition the positive selectable marker gene phosphomannose isomerase (PMI) (Joersbo and Okkels 1996) has been shown to be a rather robust selection system for the identification of transgenic plants (Negrotto et al. 2000), including sorghum (Gao et al. 2005b).

\subsection{Outline of an Agrobacterium-Mediated Transformation of Sorghum Using npt II as a Selectable Marker Gene}

As indicated above there have been multiple reports of successful transformation of sorghum following the communicated success in 1993 (Casas et al. 1993). Outlined below is the system reported on by Howe et al. (2006) that utilizes npt II as the selectable marker gene, coupled with G418 a the selection agent. While the overall transformation efficiency with this system is relatively low, typically ranging from 1 to $3 \%$, the system is consistent, and importantly teachable with minimal training.

This sorghum transformation system relies upon immature embryos as the starting material. One of the disadvantages of using this explant is the need for continual plantings of stock plants to ensure a constant supply of immature embryos, adding labor and cost to the system. Nonetheless, the stock plants used to supply immature embryos are maintained under greenhouse conditions. Heads are harvested when $70 \%$ of the head have embryos ranging in size from 1.2 to $2.2 \mathrm{~mm}$ in length. Each head is then excised from the plant and placed in a 1,000 ml graduated cylinder filled with $500 \mathrm{ml}$ of $50 \%$ commercial bleach plus 
$250 \mathrm{ml}$ of Tween 20. The cylinder containing the sorghum head submerged in the bleach solution is mixed with a stir bar for $20 \mathrm{~min}$. Following the $20 \mathrm{~min}$ surface sterilization with bleach the heads are washed three times with sterile water and allowed to air dry in laminar flow hood. Seeds are isolated and subjected to a secondary sterilization process consisting of a $1 \mathrm{~min}$ soak with agitation in $70 \%$ ethanol, followed by a single wash with sterile water, proceeded by a soak with agitation in $10 \%$ bleach solution, with a subsequent triple wash in sterile water.

Immature embryos are isolated from 50 sterilized seeds and placed in a $35 \times 10 \mathrm{~mm}$ Petri plate containing $1 \mathrm{ml}$ of coculture medium supplemented with $300 \mu \mathrm{M}$ of acetosyringone. The coculture medium is composed of $0.5 \times$ MS major and minor salts (Murashige and Skoog 1962), $0.5 \mathrm{mg} / 1$ each of nicotinic acid and pyridoxine $\mathrm{HCl}$, plus $1 \mathrm{mg} / 1$ each of thiamine $\mathrm{HCl}$ and casamino acids. The carbohydrate sources are $2 \%$ sucrose and $1 \%$ glucose and growth regulator, 2,4-d, at $2 \mathrm{mg} / \mathrm{l}$. The medium is buffered with $3 \mathrm{mM}$ MES ( $\mathrm{pH} \mathrm{5.2).} \mathrm{The} \mathrm{medium} \mathrm{is} \mathrm{filter}$ sterilized, with no components being autoclaved.

Once 50 immature embryos have been isolated the coculture medium is removed and replaced with $1 \mathrm{ml}$ of $A$. tumefaciens inoculum. The inoculum is an $A$. tumefaciens strain NTL 4 / pTiPKPSF2 (Palanichelvam et al. 2000), suspension in cocultivation medium $\left(\mathrm{OD}_{660} 0.3-0.5\right)$. Inoculation time is $5 \mathrm{~min}$. Following the cocultivation step the explants are placed scutellum side up on $100 \times 20 \mathrm{~mm}$ Petri plates containing four sterile Whatman ${ }^{\mathrm{TM}}$ filter papers saturated with $4.2 \mathrm{ml}$ of cocultivation medium. The plates are incubated for 2 days at $24^{\circ} \mathrm{C}$ in the dark.

Following the cocultivation period the explants are cultured on delay medium which is composed of Elkonin's major salts (Elkonin and Pakhomova 2000), MS minor salts and vitamin mix, $2 \mathrm{~g} / 1$ proline, and $1 \mathrm{~g} / 1$ asparagine. The carbohydrate source is $3 \%$ sucrose, the medium is buffered with $3 \mathrm{mM}$ MES (pH 5.7) and solidified with $2 \%$ phytagel. To counter select against $\mathrm{A}$. tumefcaiens the medium is supplemented with $100 \mathrm{mg} / 1$ carbenicillin. The growth regulator 2,4-d is used at a level of $1.5 \mathrm{mg} / 1$. Cultures are incubated at $28^{\circ} \mathrm{C}$ in the dark for 3 days.

The selection phase is immediately implemented following the delay period. A total of 20 embryos are placed on to $100 \times 20 \mathrm{~mm}$ Petri plates containing the delay medium supplemented with $20 \mathrm{mg} / 1 \mathrm{G} 418$. The tissue is transferred to fresh selection medium every 2-3 weeks. As coleoptiles develop they are systematically removed from the explants. As the embryogenic callus begins to form about the explants the tissue is broken up into 1-3 mm pieces, with care being taken to ensure tracking of tissue from the original explant, given the fact that most transformants derived from the same initial immature embryo tend to be clones, and hence the best way to track transformation efficiencies. The callus tissue remains in the selection phase for a period of 6-9 weeks.

Following the selection phase proliferating embryogenic tissue is transferred to regeneration medium composed of MS major/minor salts and vitamins, supplemented with $0.5 \mathrm{mg} / 1$ kinetin and $1.0 \mathrm{mg} / 1 \mathrm{IAA}$. The medium is solidified with $2 \%$ phytagel, carbohydrate level, $3 \%$ sucrose, and buffered with $3 \mathrm{mM}$ MES ( $\mathrm{pH}$ 5.7). The selection pressure is reduced to $10 \mathrm{mg} / 1 \mathrm{G} 418$, and the carbenicillin level remains at $100 \mathrm{mg} / 1$. The cultures are placed under a 16/8 light regime at 
Figure 1. Overview of sorghum transformation steps. (a) Sterilization step of immature seeds. (b) Inoculation step of immature embryos. (c) Somatic embryogeneic tissue. (d) Partitioning of somatic embryogenic tissue to ensure lineage tracking. (e, f) Regeneration steps.

(g) Acclimation of plants.

(h) Transgenic sorghum in greenhouse.
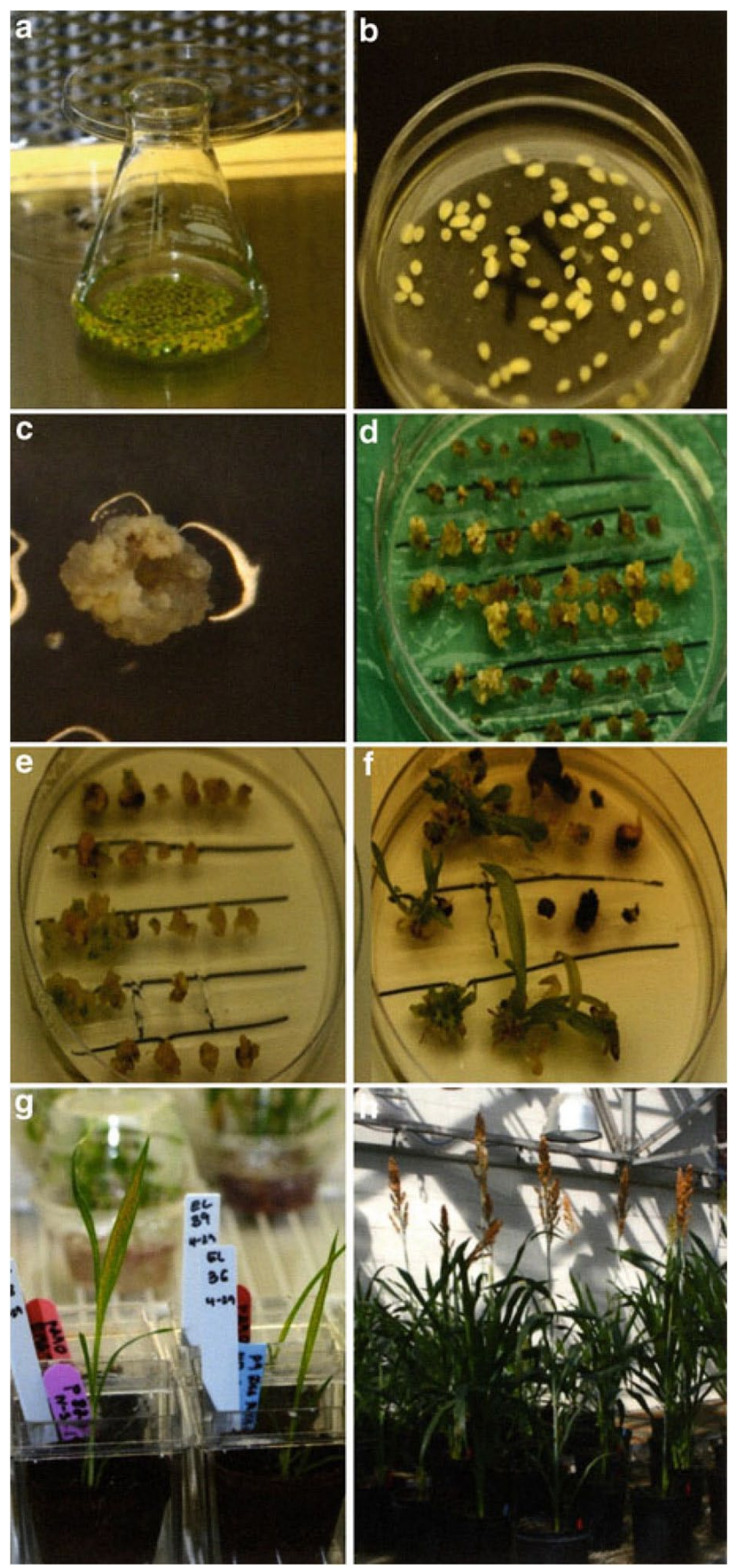

$24^{\circ} \mathrm{C}$. Typically after 4 weeks on regeneration, with one subculture at the 2-week period, shoots with well established roots will form, that are ready to be acclimated to soil (Figure 1). 
Once acclimated the primary transformants are confirmed using a commercial ELISA kit to monitor npt II expression (Agdia Corp.). Primary transformants are screened to identify a minimum of two lead events for down-stream characterizations. A lead event is selected based on simple integration pattern of the transgenic element(s), and expression of the target phenotype(s) of interest.

\section{Considerations in Designing Binary Vectors for Sorghum Transformation}

An attribute of Agrobacterium-mediated transformation is that T-DNAs can be integrated, albeit relatively infrequently, at unlinked positions. This ability of A.tumefaciens can be exploited to derived marker-free transgenic events through the simultaneous delivery of two T-DNAs, where one of the T-DNA elements carries the marker gene, and the other carries gene(s) of interest. If integrated at unlinked positions, the T-DNAs, will segregate in the progeny. This strategy has been successfully used to derived maker-free transgenic plants in a number of systems (Daley et al. 1998; Jacob and Veluthambi 2002; Komari et al. 1996; Sato et al. 2004b; Xing et al. 2000), including sorghum (Zhao et al. 2003). The integration of unlinked T-DNA alleles in sorghum is exemplified in Figure 2. Transgenic sorghum events were generated that harbored a transgenic cassette with the cyanamide hydratase (cah) gene (Maier-Greiner et al. 1991), under control of the sugarcane polyubiquitin promoter ubi4 (Wei et al. 2003), housed within a single T-DNA binary vector designated pPTN181 (not shown). A Southern blot analysis is performed using a restriction enzyme wherein one recognition site resides within the T-DNA element, hence each hybridization signal will reflect a single integration locus, on a subset of primary transformants derived from pPTN181 as shown in Figure 2a. As can be seen the event 168 carries one locus, while events 165 and 166 harbor two loci, and event 164 contains three loci. Monitoring segregation of the transgenic alleles in progeny derived from these events revealed a 15:1 pattern for events 165 and 166, and a 3:1 pattern for events 164 and 168 (data not shown). Southern analysis on a subset of the derived progeny is in agreement with the observed segregation patterns (Figure $2 b, c)$. It can be seen in the $T_{1}$ individuals derived from events 165 and 166 that some individuals display the genotype of the parent, while others only carry one of the transgenic alleles. On the other hand all $\mathrm{T}_{1}$ derived from event 164 had the same genotype as the parent, hence all alleles appear to be linked. However the single locus event, 168, segregated as expected, with $\mathrm{T}_{1}$ individuals genotyped the same as the parent.

When implementing the tool of plant transformation for targeted output and input traits in sorghum such as improvement in grain quality or stress tolerance, respective, it is critical to have promoter elements with the desired specificity so to limit the probability of negatively impacting agronomic performance that may arise if the phenotype is misexpressed in nontarget tissues. To this end it is prudent to verify promoter specificity if using a promoter known to be tissue specific 
Figure 2. Southern blot analysis of transgenic sorghum events carrying cyanamide hydratase (cah) gene. (a) Primary transformation events designated 164, 165, 166, and 168 probed with cah ORF. + lane indicates 50 pg linear binary vector pPTN181. Tx430 lane is $10 \mu \mathrm{g}$ of wild type DNA. (b) Southern blot analysis of $\mathrm{T}_{1}$ progeny derived from events 164 and 165, highlighting segregating transgenic alleles in event 165 , and linked alleles in 164. WT lane indicates 10 $\mu \mathrm{g}$ genomic DNA from Tx430. + lane is $50 \mathrm{pg}$ of linear binary vector pPTN181. (c) Southern blot analysis of $T_{1}$ progeny derived from events 166 and 168, highlighting segregating transgenic alleles in event 166, and linked locus in 168. WT lane indicates $10 \mu \mathrm{g}$ genomic DNA from Tx430. + lane is $50 \mathrm{pg}$ of linear binary vector $\mathrm{pPTN} 181$.

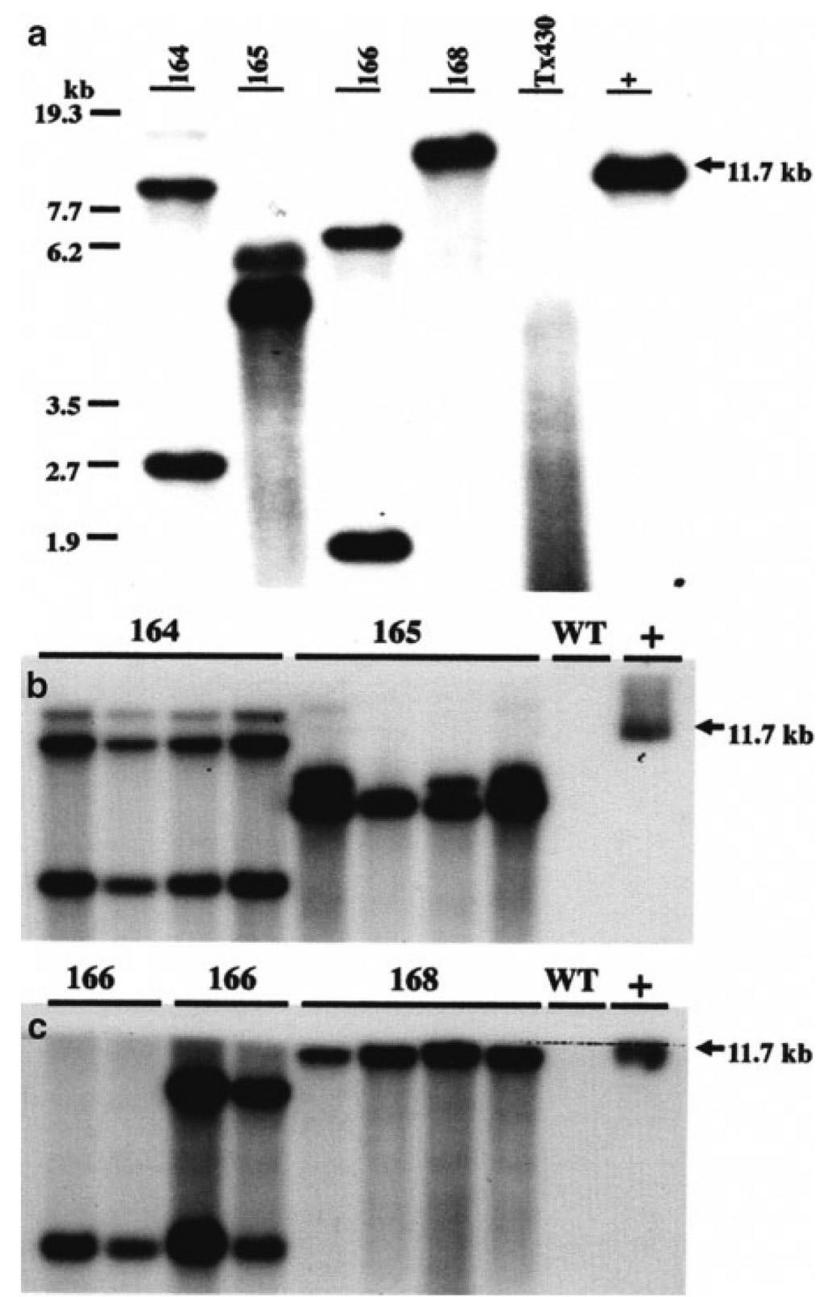

in other species, before assembling cassettes for use in sorghum. For example interest in modifying seed components of sorghum may require specific expression in the embryo. A logical candidate promoter for desired embryo-specific expression would be the maize globulin-1 promoter (Belanger and Kriz 1991). To evaluate whether the glob-1 promoter specificity would translate to sorghum a GUSPlus $^{\mathrm{TM}}$ (www.cambia.org) cassette under control of the glob-1 promoter was assembled and introduced into sorghum. As a constitutive control transgenic sorghum carrying a GUSPlus ${ }^{\mathrm{TM}}$ cassette under control of the maize polyubiquitin promoter (Christensen et al. 1992) was used for comparison. Tissue samples were assayed over development in $\mathrm{T}_{1}$ or $\mathrm{T}_{2}$ individuals, looking at GUS expression within root, leaf, stem, glume, scutellum, and embryos. As can be seen in Figure 3 , embryo-specificity of the maize glob-1 promoter does effectively translate to sorghum. While this result is not surprising, these are data that need to be gathered to fully exploit sorghum transformation as a translational genomics tool. 

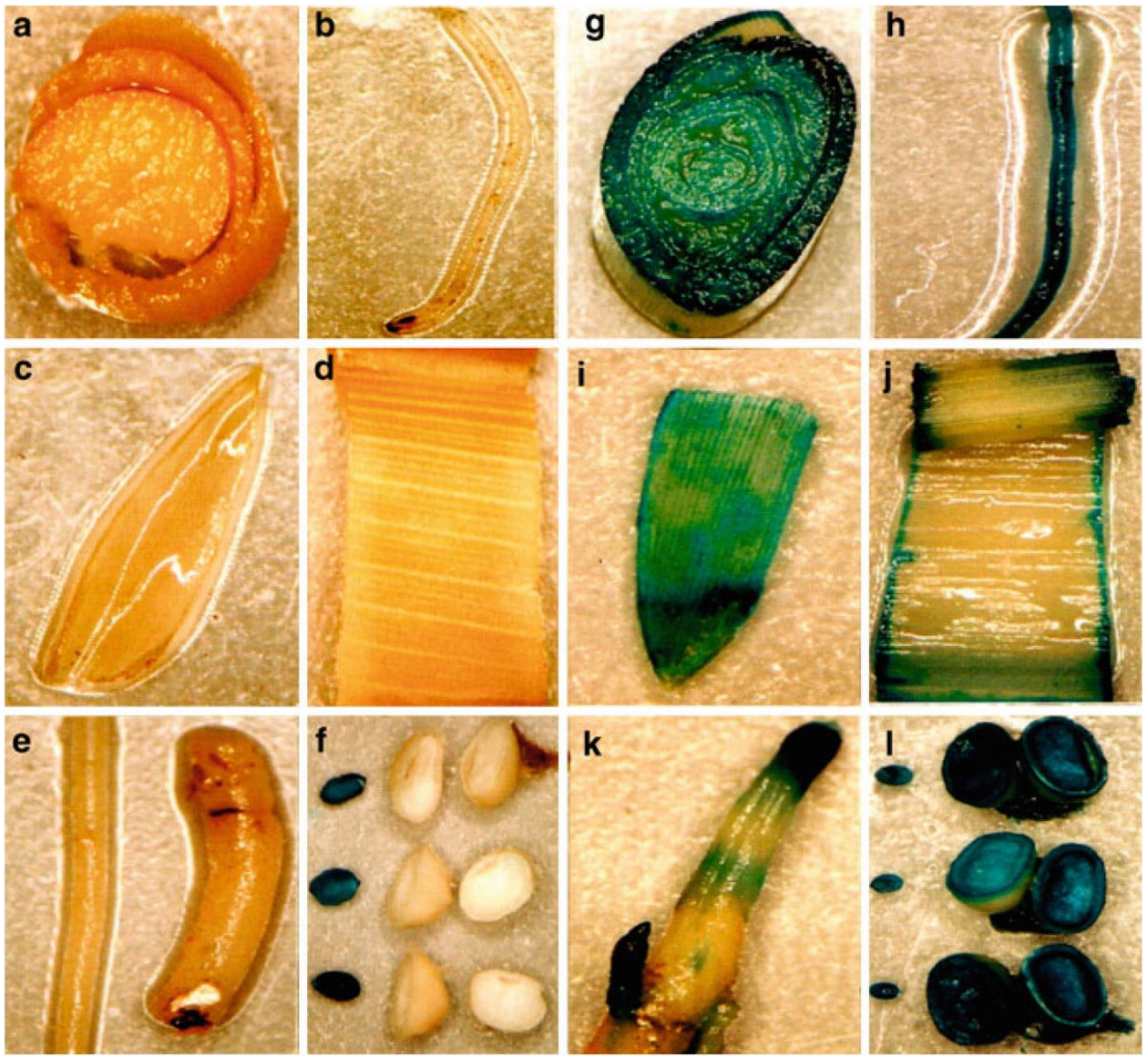

Figure 3. GUS expression profile observed in transgenic sorghum. Panels (a-f): Transgenic sorghum event carrying the glob-1-GUS cassette showing embryo specific expression. (a) Stem section, (b) root section, (c) glume, (d) leaf, (e) root, and (f) seed, endosperm and embryo (blue). Panels (g-l): Transgenic sorghum event carrying the ubiquitin-1-GUS cassette showing constitutive GUS expression. (g) Stem section, (h) root section, (i) glume, (j) leaf, (k) root, and (l) seed, endosperm and embryo.

\section{Target Input Traits for Sorghum Through Transformation}

A critical trait for any breeding program is yield. Addressing yield directly through transgenic approaches is a rather large challenge. A more practical and obtainable goal in the short term is protection of yield through control of biotic and abiotic stresses. In sorghum, like most crops, key stresses that compromise yield will vary across regions. Sorghum production can be severely impacted by a number of insect pests. Not only can insects impact production directly, but in some cases they can also provide an entry for secondary pathogen attack at the site of insect feeding. The success of the Bt technology in maize (Armstrong et al. 1995; Barry et al. 2000), and cotton (Cattaneo et al. 2006), is a strong rationale for 
the evaluation of this technology in sorghum as a means to combat specific target insect pests. Importantly, in addition to $B t^{\prime}$ s direct impact in impeding insect pest feeding damage, a secondary effect observed with the use of this technology is a significant reduction in accumulation of various mycotoxins in plant tissues (Abbas et al. 2008; Bakan et al. 2002; Hammond et al. 2004). This secondary attribute of the $B t$ technology may serve as a valuable mechanism to limit quality issues of sorghum related to contamination of these toxins that may occur under certain conditions and fungal infestation levels (Ghali et al. 2009; Reddy and Raghavender 2008; Reddy et al. 2010). However, like all disease resistance traits, the $B t$ technology needs to be used in conjunction with proper integrated pest management practices to maximize its durability over time (Kumar and Pandey 2008; Sharma and Ortiz 2000).

A number of viral agents have been shown to be capable of replication in sorghum (Jensen and Giorda 2002), including members of the potyvirus family including sugarcane mosaic virus, maize dwarf mosaic virus, and sorghum mosaic virus. Limited resistance towards these viral agents has been identified within sorghum germplasm, although some reports have been communicated (Henzell et al. 1982). The seminal work which demonstrated introduction of viral coat protein genes in transgenic plants to confer virus resistance (Abel et al. 1986; Nelson et al. 1987; Stark and Beachy 1989), has opened the door for the translation of this technology to other plant systems, implementing various genetic constructs that target silencing of critical gene products required for the replication of the virus of interest (Beachy et al. 2003; Prins 2003), including known pathogens of sorghum (Gilbert et al. 2005). Hence, such strategies offer great potential for the introduction of durable virus resistance for sorghum.

Striga, commonly referred to as witch weed, contains two species, S. hermonthica and S. asiatica, that are parasitic on sorghum and other cereals (Aly 2007). Parasitic plant species infest nearly 50 million hectares crop plants on an annual basis, and great strides have been made in developing resistance in sorghum through conventional breeding approaches (Ejeta 2007). More recently Tuinstra et al. (2009) have communicated a herbicide seed treatment strategy that exploits the introgression of acetolactate synthase (ALS) herbicide resistance from shattercane into elite sorghum genotypes (Hennigh et al. 2010). Implementing this seedcoating approach significantly reduced Striga emergence under both greenhouse and field tests (Tuinstra et al. 2009). While this is a very promising tool to combat this devastating parasite, given that ALS inhibiting herbicides are typically classified as high risk for development of resistance, the durability of such a strategy may be limited without proper management. Hence, other approaches are needed to ensure long-term control towards Stiga. To this end, there has been a report looking at targeting critical genes in parasitic plant's life cycle by expression of hair-pin constructs in the host plant which resulted in an enhanced tolerance phenotype in the Orobanche aegyptiaca/tomato host parasite interaction (Aly et al. 2009). However, this approach was not successfully translated as a means to control to the Striga/maize parasite interaction (Yoder and Scholes 2010). Clearly additional research is required to further our understanding of the underlying biology involved during the early stages of parasitism by these plants. More efforts 
around the assembly of -omics databases that carry this information (Torres et al. 2005) are needed in order to facilitate the development of alternative control strategies towards Striga, that may serve as a complement to the herbicide seed coating approach (Tuinstra et al. 2009).

Addressing a plant's response to stresses that are governed in a multigenic fashion is more challenging than single gene traits. In order to investigate multigenic abiotic stress response traits such as drought and heat, researchers are evaluating a coordinated expression of a suite of genes triggered by exposure to the targeted stress by the introduction of a single transcription factor (Karaba et al. 2007; Nelson et al. 2007; Suzuki et al. 2005). Theses transcription-factor based technologies hold great promise as a means to reduce multigenic expressed phenotypes to a single transgene fashion (Century et al. 2008), however, the transcription factor based strategy undoubtedly will require tight regulation, necessitating the need for tissue-specific and/or inducible promoter systems.

With respect to adaptation to low nitrogen environments, Yanagisawa et al. (2004) demonstrated that expression of the maize Dof1 transcription factor improved nitrogen assimilation in transgenic plants. However, it is feasible to directly perturb nitrogen flux in plants. Nitrogen assimilation and metabolism in plants occurs through coordinated action of a variety of enzymes acting upon a variety of substrates. Two key enzymes involved in nitrogen metabolism in plants are glutamine synthetase (GS) and glutamate synthase (GOGAT). Previous studies have shown that enhancing GS or GOGAT activities can impact nitrogen metabolism in plant species (Cai et al. 2009; Good et al. 2004). Enhancing activity of another enzyme that impacts nitrogen flux in plants, alanine aminotransferease (Ala-AT), that catalyzes the production of alanine and 2-oxoglutarate from pyruvate and glutamate, has been shown to augment nitrogen use efficiency in both rape seed and rice (Good et al. 2007; Shrawat et al. 2008).

A caveat to these studies communicating enhancing nitrogen use efficiency through transgenic approaches is that most reports used data sets gathered from greenhouse or growth chamber studies, with minimal information on the impact of the respective transgenes on yield under field conditions (Brauer and Shelp 2010). Moreover, no data sets have been communicated to date on the impact of gene stacking strategies on nitrogen use efficiencies with these selected genes.

\section{Target Output Traits for Sorghum Through Transformation}

Digestibility of sorghum limits protein availability, and ultimately impacts the nutritional quality of the grain (Duodu et al. 2003). The major proteins, prolamins, found in sorghum reside in the endosperm. The prolamin storage proteins found in sorghum and maize are designated kafirins and zeins, respectively. The prolamins are assembled into protein bodies, with a very defined pattern, where the a class reside in the core along with the $\delta$ class, albeit to a lower extent, while the $\beta$ and $\gamma$ classes decorate the periphery of the protein body (Wu and Messing 2010). A number of parameters can influence 
digestibility of sorghum protein, including structure and shape of the protein body (Duodu et al. 2003). Reduction of the zein proteins found in the maize mutants opaque-2 (Hartings et al. 1989) and floury-2 (Coleman et al. 1995) leads to a concomitant increase in lysine and tryptophan due to a compensation mechanism in seeds resulting in an increase in nonzein proteins (Coleman and Larkins 1999). Deliberate reduction in the $19 \mathrm{kDa}$ a-zeins in maize manifests the opaque kernel phenotype, and enhances levels of lysine and tryptophan in the grain (Huang et al. 2004). Similarly, reduction in the level of both the $\beta$ - and $\gamma$-zeins resulted in drastic changes protein bodies, and triggered the opaque kernel phenotype (Wu and Messing 2010). Hence, modulation of the prolamins is a target that could be pursued in sorghum as a means to simultaneously address digestibility, and nutritional quality.

Oria et al. (2000) described a highly digestible, enhanced lysine sorghum mutant. The protein bodies observed within this mutant are highly folded, with a redistribution of the $\gamma$-kafirin about the body. These factors lead to increased exposure of the core a-kafirins, which translates to the increased digestibility phenotype (Duodu et al. 2003).

Like the maize floury-2 and opaque-2 mutants, the highly digestible, enhanced lysine mutant of sorghum has value in both food and feed applications. However, translation of these traits to application has yet to be realized, undoubtedly due to the tendency of these altered prolamin grains to have reduced agronomic properties, and post harvest issues (Huang et al. 2004). However, these drawbacks may not be insurmountable. Breeding efforts are making progress in addressing the issues blocking deployment of the high digestible, enhanced lysine mutant of sorghum (Tesso et al. 2006, 2008a). Through better understanding of the underlying biology governing protein deposition in these mutants and the influence of the various genetic modifiers, will lead to improved biotechnology approaches, coupled with better breeding strategies, to modulate the seed storage proteins, without negatively altering the endosperm characteristics. Hence, in the end, the successful deployment of a high quality grain sorghum will ultimately require an interdisciplinary approach that brings together the expertise of plant breeding, biotechnology, molecular biology/genetics and food science.

\section{Potential of Outcrossing}

One of the concerns raised about release of transgenic sorghum is the potential for outcrossing to its weedy relatives, johnsongrass and shattercane, which has been hypothesized to potentially lead to altered balance in the ecosystem, changes in the plant community structure, and persistence of weeds in agricultural lands (Tesso et al. 2008b).

A number of parameters must be met for a successful sorghum outcross event to occur. First, the crop and weed species must be in close proximity, and flowering times synchronized. Hybrids derived from outcrosses between grain sorghum and shattercane (S. bicolor subsp. drummondii Nees ex Steud de Wet \& 
Harlan) do not appear to be compromised in fitness (Sahoo et al. 2010). This lack of fitness drag in sorghum $\times$ shattercane hybrids has a benefit when introgressing desirable alleles from the shattercane into the cultivated genotypes, for example ALS resistance (Hennigh et al. 2010). However, this attribute that benefits conventional breeding strategies used to broaden diversity of cultivated sorghum, negatively impacts the use of transformation as a tool for introduction of novel traits into the crop, given there will undoubtedly be a call for more extensive regulatory testing addressing the potential ecological impact of a given transgenic sorghum event, which in turn will lead to higher costs and delay in release, with getting a transgenic sorghum event on the market.

One approach that may limit the concern of transgenic sorghum impacting the ecosystem above what is already occurring with production of conventional cultivars is the use of a male sterility system that may effectively limit pollen flow of transgenic sorghum under field conditions (Pedersen et al. 2003). However, such containment systems in many cases may not be required. The current regulatory system has a "one size fit all approach," in that regardless of the trait developed through transgenic approaches, a series of laborious and costly studies must be conducted. While it is very reasonable to assume that deployment of a transgenic sorghum event will eventually outcross to a wild relative, this must not be the deciding factor to block production. Rather than a one size fits all model, perhaps a more thoughtful, scientific regulatory process, in which decisions are made on a case-by-case model is more appropriate. Recently, Hokanson et al. (2010) have communicated a straightforward and scientific-fact based risk assessment process that hopefully will open the door for more dialog in this area, and ultimately will allow for advances in transgenic technologies to enter the marketplace expeditiously in a safe and effective manner.

\section{References}

Abbas HK, Accinelli C, Zablotowicz RM, Abel CA, Bruns HA, Dong Y, Shier WT (2008) Dynamics of mycotoxin and Aspergillus flavus levels in aging $B t$ and non-Bt corn residues under Mississippi no-till conditions. J Agric Food Chem 56:7578-7585

Abel PP, Nelson RS, De B, Hoffmann N, Rogers SG, Fraley RT, Beachy RN (1986) Delay of disease development in transgenic plants that express the tobacco mosaic virus coat protein gene. Science 232:738-743

Aly R (2007) Conventional and biotechnological approaches for control of parasitic weeds. In Vitro Cell Dev Biol 43:304-317

Aly R, Cholakh H, Joel DM, Leibman D, Steinitz B, Zelcer A, Naglis A, Yarden O, Gal-On A (2009) Gene silencing of mannose 6-phosphate reductase in the parasitic weed Orobanche aegyptiaca through the production of homologous dsRNA sequences in the host plant. Plant Biotechnol J 7:487-498

Armstrong CL, Parker GB, Pershing JC, Brown SM, Sanders PR, Duncan DR, Stone T, Dean DA, DeBoer DL, Hart J, Howe AR, Morrish FM, Pajeau ME, Peterson WL, Reich BJ, Rodriguez R, Santino CG, Sato SJ, Schuler W, Sims SR, Stehling S, Tarochione LJ, Fromm ME (1995) Field evaluation of european corn borer control in progeny of 173 transgenic corn events expressing an insecticidal protein from Bacillus thuringiensis. Crop Sci 35:550-557 
Bakan B, Melcion D, Richard-Molard D, Cahagnier B (2002) Fungal growth and fusarium mycotoxin content in isogenic traditional maize and genetically modified maize grown in France and Spain. J Agric Food Chem 50:728-731

Barry BD, Darrah LL, Huckla DL, Antonio AQ, Smith GS, O'Day MH (2000) Performance of transgenic corn hybrids in Missouri for insect control and yield. J Econ Entomol 93:993-999

Barry G, Kishore G, Padgette S, Taylor M, Kolacz K, Weldon M, Re D, Eichholtz D, Fincher K, Hallas L (1992) Inhibitors of amino acid biosynthesis: strategies for imparting glyphosate tolerance to crop plants. Biosynthesis and molecular recognition of amino acids in plants. 139-145

Battraw M, Hall TC (1991) Stable transformation of Sorghum bicolor protoplasts with chimeric neomycin phosphotransferase-II and $\beta$-glucuronidase genes. Theor Appl Genet 82:161-168

Beachy RN, Fraley RT, Rogers SG (2003) Protection of plants against viral infection. Monsanto Technology LLC/Washington University, United States Patent No. 6,608,421

Belanger FC, Kriz AL (1991) Molecular basis for allelic polymorphism of the maize Globulin-1 gene. Genetics 129:863-872

Brauer EK, Shelp BJ (2010) Nitrogen use efficiency: re-consideration of the bioengineering approach. Botany 88:103-109

Cai H, Zhou Y, Xiao J, Li X, Zhang Q, Lian X (2009) Overexpressed glutamine synthetase gene modifies nitrogen metabolism and abiotic stress responses in rice. Plant Cell Rep 28:527-537

Cai T, Daly B, Butler L (1987) Callus induction and plant regeneration from shoot portions of mature embryos of high tannin sorghum. Plant Cell Tiss Org Cult 9:245-252

Cai T, Pierce DA, Tagliani LA, Zhao Z-Y (2002) Agrobacterium mediated transformation of sorghum. Pioneer Hi-Bred International, Inc, United States Patent No. 6,396,298

Casas AM, Kononowicz AK, Zehr UB, Tomes DT, Axtell JD, Butler LG, Bressan RA, Hasegawa PM (1993) Transgenic sorghum plants via microprojectile bombardment. Proc Natl Acad Sci USA 90:11212-11216

Cattaneo MG, Yafuso C, Schmidt CW, Huang C-Y, Rahman M, Olson C, Ellers-Kirk C, Orr BJ, Matsh SE, Antilla L, Dutilleul P, Carriére Y (2006) Farm-scale evaluation of the impacts of transgenic cotton on biodiversity, pesticide use, and yield. Proc Natl Acad Sci USA 103:7571-7576

Century K, Reuber TL, Ratcliffe OJ (2008) Regulating the regulators: the future prospects for transcription-factor-based agricultural biotechnology products. Plant Physiol 147:20-29

Christensen AH, Sharrock RA, Quail PH (1992) Maize polyubiquitin genes: structure, thermal perturbation of expression and transcript splicing, and promoter activity following transfer to protoplasts by electroporation. Plant Mol Biol 18:675-689

Coleman CE, Larkins BA (1999) The prolamins of maize. In: Shewry PR, Casey R (eds) Seed proteins. Kluwer Academic Publishers, Dordrecht, pp 109-139

Coleman CE, Lopes MA, Gillikin JW, Boston RS, Larkins BA (1995) A defective signal peptide in the maize high-lysine mutant floury 2. Proc Natl Acad Sci USA 92:6828-6831

Cook D, Rimando AM, Clemente TE, Schroder J, Dayan FE, Nanayakkara D, Pan Z, Noonan BP, Fishbein M, Abe I, Duke SO, Baerson SR (2010) Alkylresorcinol. synthases expressed in Sorghum bicolor root hairs play an essential role in the biosynthesis of the allelopathic benzoquinone soroleone. Plant Cell 22:867-887

Dai S, Zheng P, Marmey P, Zhang S, Tian W, Chen S, Beachy RN, Fauquet C (2001) Comparative analysis of transgenic rice plants obtained by Agrobacterium-mediated transformation and particle bombardment. Mol Breed 7:25-33 
Daley M, Knauf VC, Summerfelt KR, Turner JC (1998) Co-transformation with one Agrobacterium tumefaciens strain containing two binary plasmids as a method for producing marker-free transgenic plants. Plant Cell Rep 17:489-496

Duodu KG, Taylor JRN, Belton PS, Hamaker BR (2003) Factors affecting sorghum protein digestibility. J Cereal Sci 38:117-131

Ejeta G (2007) Breeding for Striga resistance in sorghum: exploitation of an intricate hostparasite biology. Crop Sci 47(suppl 3):216-227

Elkonin LA, Pakhomova NV (2000) Influence of nitrogen and phosphorus on induction embryogenic callus of sorghum. Plant Cell Tiss Org Cult 61:115-123

Fraley RT, Rogers SG, Horsch RB, Sanders PR, Flick JS, Adams SP, Bittner ML, Brand LA, Fink CL, Fry JS, Galluppi GR, Goldberg SB, Hoffmann NL, Woo SC (1983) Expression of bacterial genes in plant cells. Proc Natl Acad Sci USA 80:4803-4807

Gao C, Long D, Lenk I, Nielsen KK (2008) Comparative analysis of transgenic tall fescue (Festuca arundinacea Schreb.) plants oBtained by Agrobacterium-mediated transformation and particle bombardment. Plant Cell Rep 27:1601-1609

Gao Z, Jayaraj J, Muthukrishnan S, Claflin L, Liang GH (2005a) Efficient genetic transformation of sorghum using a visual screening marker. Genome 48:321-333

Gao Z, Xie X, Ling Y, Muthukrishnan S, Liang GH (2005b) Agrobacterium tumefaciens-mediated sorghum transformation using a mannose selection system. Plant Biotechnol J 3:591-599

Ghali R, Ghorbel H, Hedilli A (2009) Fumonisin determination in Tunisian foods and feeds. ELISA and HPLC methods and comparison. J Agric Food Chem 57:3955-3960

Gilbert RA, Gallo-Meagher M, Comstock JC, Miller JD, Jain M, Abouzid A (2005) Agronomic evaluation of sugarcane lines transformed for resistance to sugarcane mosic virus strain E. Crop Sci 45:2060-2067

Good AG, Johnson SJ, De Pauw M, Carroll RT, Savidov N, Vidmar J, Lu Z, Taylor GJ, Stroeher V (2007) Engineering nitrogen use efficiency with alanine aminotransferase. Can J Bot 85:252-262

Good AG, Shrawat AK, Muench DG (2004) Can less yield more? Is reducing nutrient input into the environment compatible with maintaining crop production? Trends Plant Sci 9:597-605

Gritz L, Davies J (1983) Plasmid-encoded hygromycin B resistance: the sequence of hygromycin B phosphotransferase gene and its expression in Escherichia coli and Saccaromyces cerevisiae. Gene 26:179-188

Gurel S, Gurel E, Kaur R, Wong J, Meng L, Tan H-Q, Lemaux PG (2009) Efficient, reproducible Agrobacterium-mediated transformation of sorghum using heat treatment of immature embryos. Plant Cell Rep 28:429-444

Hammond BG, Campbell KW, Pilcher CD, Degooyer TA, Robinson AE, McMillen BL, Spangler SM, Riordan SG, Rice LG, Richard JL (2004) Lower fumonisin mycotoxin levels in the grain of Bt corn grown in the United States in 2000-2002. J Agric Food Chem 52:1390-1397

Hartings H, Maddaloni M, Lazzaroni N, Di Fonzo N, Motto M, Salamini F, Thompson R (1989) The $\mathrm{O} 2$ gene which regulates zein deposition in maize endosperm encodes a protein with structural homologies to transcriptional activators. EMBO J 8:2795-2801

Hennigh DS, Al-Khatib K, Currie RS, Tuinstra MR, Geier PW, Stahlman PW, Claassen MM (2010) Weed control with selected herbicides in acetolactate synthase-resistant sorghum. Crop Protect 29:879-883

Henzell RG, Persley DM, Greber RS, Fletcher DS, Van Slobbe L (1982) Development of grain sorghum lines with resistance to sugarcane mosaic and other sorghum diseases. Plant Dis 66:900-901 
Hokanson KE, Ellstrand NC, Ouedraogo JT, Olweny PA, Schaal PA, Raybould AF (2010) Biofortified sorghum in Africa: using problem formulation to inform risk assessment. Nat Biotechnol 28:900-903

Howe A, Sato S, Dweikat I, Fromm M, Clemente T (2006) Rapid and reproducible Agrobacterium-mediated transformation of sorghum. Plant Cell Rep 25:784-791

Huang S, Adams WR, Zhou Q, Malloy KP, Voyles DA, Anthony J, Kriz AL, Luethy MH (2004) Improving nutritional quality of maize proteins by expressing sense and antisense zein genes. J Agric Food Chem 52:1958-1964

Jacob SS, Veluthambi K (2002) Generation of selection marker-free transgenic plants by cotransformation of a cointegrate vector T-DNA and a binary vector T-DNA in one Agrobacterium tumefaciens strain. Plant Sci 163:801-806

Jensen SG, Giorda LM (2002) Virus diseases of sorghum and millet in the Americas and Australia. In: Leslie JF (ed) Sorghum and millets diseases. Iowa State, Ames, IA, pp 403-410

Jeoung JM, Krishnaveni S, Muthukrishnan S, Trick HN, Liang GH (2002) Optimization of sorghum transformation parameters using genes for green fluorescent protein and $\beta$-glucuronidase as visual markers. Hereditas 137:20-28

Joersbo M, Okkels FT (1996) A novel principle for selection of transgenic plant cells: positive selection. Plant Cell Rep 16:219-221

Jogeswar G, Ranadheer D, Anjaniah V, Kishor PBK (2007) High frequency somatic embryogenesis and regeneration in different genotypes of Sorghum bicolor (L.) Moench from immature explants. In Vitro Cell Dev Biol-Plant 43:159-166

Kaeppler HF, Pedersen JF (1996) Media effects on phenotype of callus cultures initiated from photoperiod-insensitive, elite inbred sorghum lines. Maydica 41:83-89

Karaba A, Dixit S, Greco R, Aharoni A, Trijatmiko KR, Marsch-Martinez N, Nataraja K, Udayakumar M, Pereira A (2007) Improvement of water use efficiency in rice by expression of HARDY, an Arabidopsis drought and salt gene. Proc Natl Acad Sci USA 104:15270-15275

Khanna H, Becker D, Kleidon J, Dale J (2004) Centrifugation assisted Agrobacterium tumefaciens-mediated transformation (CAAT) of embryogenic cell suspensions of banana (Musa spp. Cavendish AAA and Lady finger AAB). Mol Breed 14:239-252

Khanna HK, Paul J-Y, Harding RM, Dickman MB, Dale JL (2007) Inhibition of Agrobacterium-induced cell death by antiapoptotic gene expression leads to very high transformation efficiency of banana. Mol Plant Microb Interact 20:1048-1054

Komari T, Hiei Y, Saito Y, Murai N, Kumashiro T (1996) Vectors carrying two separate T-DNAs for co-transformation of higher plants mediated by Agrobacterium tumefaciens and segregation of transformants free from selection markers. Plant J 10:165-174

Kumar S, Pandey KC (2008) Bacillus thuringiensis (Bt) transgenic crop: an environment friendly insect-pest management strategy. J Environ Biol 29:641-653

Maier-Greiner UH, Obermaier-Skrobranek BM, Estermaier LM, Kammerloher W, Freund C, Wulfing C, Burkert UI, Matern DH, Breuer M, Eulitz M et al (1991) Isolation and properties of a nitrile hydratase from the soil fungus Myrothecium verrucaria that is highly specific for the fertilizer cyanamide and cloning of its gene. Proc Natl Acad Sci USA 88:4260-4264

Murashige T, Skoog F (1962) A revised medium for rapid growth and bioassays with tobacco tissue cultures. Physiol Plant 15:473-497

Negrotto D, Jolley M, Beer S, Wenck AR, Hansen G (2000) The use of phosphomannoseisomerase as a selectable marker to recover transgenic maize plants (Zea mays L.) via Agrobacterium transformation. Plant Cell Rep 19:798-803

Nelson DE, Repetti PP, Adams TR, Creelman RA, Wu J, Warner DC, Anstrom DC, Bensen 
RJ, Castiglioni PP, Donnarummo MG, Hinchey BS, Kumimoto RW, Maszle DR, Canales RD, Krolikowski KA, Dotson SB, Gutterson N, Ratcliffe OJ, Heard JE (2007) Plant nuclear factor $\mathrm{Y}$ (NF-Y) B subunits confer drought tolerance and lead to improved corn yields on water-limited acres. Proc Natl Acad Sci USA 104:16450-16455

Nelson RS, Abel PP, Beachy RN (1987) Lesions and virus accumulation in inoculated transgenic tobacco plants expressing the coat protein gene of tobacco mosaic virus. Virology 158:126-132

Nguyen T-V, Thu TT, Claeys M, Angenon G (2007) Agrobacterium-mediated transformation of sorghum (Sorghum bicolor (L.) Moench) using an improved in vitro regeneration system. Plant Cell Tiss Org Cult 91:155-164

Oria MP, Hamaker BR, Axtell JD, Huang C-P (2000) A highly digestible sorghum mutant cultivar exhibits a unique folded structure of endosperm protein bodies. Proc Natl Acad Sci USA 97:5065-5070

Palanichelvam K, Oger P, Clough SJ, Cha C, Bent AF, Farrand SK (2000) A second T-region of the soybean-supervirulent chrysopine-type Ti plasmid pTiChry5, and construction of a fully disarmed vir helper plasmid. Mol Plant Microb Interact 13:1081-1091

Paterson AH (2008) Genomics of sorghum. Int J Plant Genomics 2008:6

Paterson AH, Bowers JE, Bruggmann R, Dubchak I, Grimwood J, Gundlach H, Haberer G, Hellsten U, Mitros T, Poliakov A, Schmutz J, Spannagl M, Tang H, Wang X, Wicker T, Bharti AK, Chapmann J, Feltus FA, Gowik U, Grigoriev IV, Lyons E, Maher CA, Martis M, Narechania A, Otillar RP, Penning BW, Salamov AA, Wang Y, Zhang L, Carpita NC, Freeling M, Ginggle AR, Hash CT, Keller B, Klein P, Kresovich S, McCann MC, Ming R, Peterson DG, Rahman M, Ware D, Westhoff P, Mayer KFX, Messing J, Rokhsar DS (2009) The Sorghum bicolor genome and the diversification of grasses. Nature 457:551-556

Pedersen JF, Marx DB, Funnell DL (2003) Use of A3 cytoplasm to reduce risk of gene flow through sorghum pollen. Crop Sci 43:1506-1509

Pola S, Mani NS, Ramana T (2008) Plant tissue culture studies in Sorghum bicolor: immature embryo explants as the source material. Int J Plant Prod 2:1-14

Pola SR, Mani NS (2006) Somatic embryogenesis and plantlet regeneration in Sorghum bicolor (L.) Moench, from leaf explants. J Cell Mol Biol 5:99-107

Prins M (2003) Broad virus resistance in transgenic plants. Trends Biotechnol 21:373-375

Reddy BN, Raghavender C (2008) Outbreaks of Fusarial-toxicoses in India. Cereal Res Commun 36(Suppl B):321-325

Reddy KRN, Raghavender CR, Reddy BN, Salleh B (2010) Biological control of Aspergillus flavus growth and subsequent aflatoxin $B_{1}$ production in sorghum grains. Afr J Biotechnol 9:4247-4250

Sahoo L, Schmidt JJ, Pedersen JF, Lee DJ, Lindquist JL (2010) Growth and fitness components of wild X cultivated Sorghum bicolor (Poacheae) hybrids in Nebraska. Am J Bot 97:1610-1617

Sato S, Clemente T, Dweikat I (2004a) Identification of an elite sorghum genotype with high in vitro performance capacity. In Vitro Cell Dev Biol 40:57-60

Sato S, Xing A, Ye X, Schweiger B, Kinney A, Graef G, Clemente T (2004b) Production of $\mathrm{Y}$-linolenic acid and stearidonic acid in seeds of marker-free transgenic soybean. Crop Sci 44:646-652

Sharma HC, Ortiz R (2000) Transgenics, pest management, and the environment. Curr Sci 79:421-437

Shrawat AK, Carroll RT, DePauw M, Taylor GJ, Good AG (2008) Genetic engineering of improved nitrogen use efficiency in rice by the tissue-specific expression of alanine aminotransferase. Plant Biotechnol J 6:722-732 
Stark DM, Beachy RN (1989) Protection against potyvirus infection in transgenic plants: evidence for broad spectrum resistance. Nat Biotechnol 7:1257-1262

Suzuki N, Rizhsky L, Liang H, Shuman J, Shulaev V, Mittler R (2005) Enhanced tolerance to environmental stress in transgenic plants expressing the transcriptional coactivator multiprotein bridging factor $1 \mathrm{c}^{1[\mathrm{w}]}$. Plant Physiol 139:1313-1322

Tesso T, Ejeta G, Chandrashekar A, Huang C-P, Tandjung A, Lewamy M, Axtell JD, Hamaker BR (2006) A novel modified endosperm texture in a mutant high-protein digestibility/high-lysine grain sorghum (Sorghum bicolor (L.) Moench). Cereal Chem 83:194-201

Tesso T, Hamaker BR, Ejeta G (2008a) Sorghum protein digestibility is affected by dosage of mutant alleles in endosperm cells. Plant Breed 127:579-586

Tesso T, Kapran I, Grenier C, Snow AA, Sweeney P, Pedersen JF, Marx DB, Bothma G, Ejeta G (2008b) The potential for crop-to-wild gene flow in sorghum in Ethiopia and Niger: a geographic survey. Crop Sci 48:1425-1431

Thompson CJ, Movva NR, Tizard R, Crameri R, Davies JE, Lauwereys M, Botterman J (1987) Characterization of the herbicide-resistance gene bar from Streptomyces hygroscopicus. EMBO 6:2519-2523

Torres MJ, Tomilov AA, Tomilova N, Reagan RL, Yoder JI (2005) Psroph, a parasitic plant EST database enriched for parasite associated transcripts. BMC Plant Biol 5:24-33

Tuinstra MR, Soumana S, Al-Khatib K, Kapran I, Toure A, van Ast A, Bastiaans L, Ochanda NW, Salami I, Kayentao M, Dembele S (2009) Efficacy of herbicide seed treatments for controlling Striga infestation of sorghum. Crop Sci 49:923-929

Wei H, Moore PH, Albert HH (2003) Comparative expression analysis of two sugarcane polyubiquitin promoters and flanking sequences in transgenic plants. J Plant Physiol 160:1241-1251

Wu Y, Messing J (2010) RNA interference-mediated change in protein body morphology and seed opacity through loss of different zein proteins. Plant Physiol 153:337-347

Xin Z, Wang M-L, Burow G, Burke J (2009) An induced sorghum mutant population suitable for bioenergy research. Bioenerg Res 2:10-16

Xing A, Zhang Z, Sato S, Staswick P, Clemente T (2000) The use of the two T-DNA binary system to derive marker-free transgenic soybeans. In Vitro Cell Dev Biol 36:456-463

Yanagisawa S, Akiyama A, Kisaka H, Uchimiya H, Miwa T (2004) Metabolic engineering with Dof 1 transcription factor in plants: Improved nitrogen assimilation and growth under low-nitrogen conditions. Proc Natl Acad Sci USA 101:7833-7838

Yoder JI, Scholes JD (2010) Host plant resistance to parasitic weeds; recent progress and bottlenecks. Curr Opin Plant Biol 13:478-484

Zhao Z-Y, Glassman K, Sewalt V, Wang N, Miller M, Chang S, Thompson T, Catron S, Wu E, Bidney D, Kedebe Y, Jung R (2003) Nutritionally improved transgenic sorghum. Kluwer Academic Publishers, Dordrecht

Zhao Z-Y, Gu W, Cai T, Tagliani LA, Hondred D, Bond D, Krell S, Rudert ML, Bruce WB, Pierce DA (1998) Molecular analysis of T0 plants transformed by Agrobacterium and comparison of Agrobacterium-mediated transformation with bombardment transformation in maize. Maize Genet Coop News Lett 72:1-4

Zhao ZY, Cai T, Tagliani L, Miller M, Wang N, Pang H, Rudert M, Schroeder S, Hondred D, Seltzer J, Pierce D (2000) Agrobacterium-mediated sorghum transformation. Plant Mol Biol 44:789-798 